\section{COVER SERIES}

\section{TENDING TO THE TOMMYS' TEETH IN WORLD WAR I}

This image (right) shows a fundraising poster for the Ivory Cross National Dental Aid Fund which inspired the cover of this issue of the $B D J$.

The plight of the 'Tommys' teeth' moved Ada Fletcher to set up the Soldiers and Sailors Dental Aid Fund in 1914 with a small committee of likeminded individuals, despite being warned of the lack of success of similar funds. Ada was involved in organising and administering a variety of charitable efforts and became aware of the need for a dental fund whilst working at the Women's Emergency Corps.

Dentists from across the country were recruited to provide the treatment and were paid a nominal fee (Table 1). It was recommended that any treatment be as conservative as possible.

Harley Street dentist Alfred Templar Barritt was the first dentist to sign up to the roll of honour. By 1922 there were 2,000 dentists signed up. There was no shortage of applicants for treatment and by May 1916 the fund had provided treatment for 15,000 soldiers and sailors rendering them fit for service. Two thousand sets of dentures were supplied for a total bill of $€ 6,000$.

As the War Office took on responsibility for providing dental services for the forces the fund re-organised and became the Ivory Cross National Dental Aid Fund in October 1916. Its purpose was to provide skilled dental treatment to discharged servicemen,

\begin{tabular}{|c|c|}
\hline Operative & \\
\hline Scaling & From $1 /-$ to $5 /-$ \\
\hline \multirow[t]{3}{*}{ Extractions } & 1/- per tooth without anaesthetic \\
\hline & 2/- per tooth with anaesthetic \\
\hline & Max fee for multiple extractions 10/- \\
\hline General anaesthesia & $\begin{array}{l}5 /- \text { is allowed for one administration. } \\
\text { Maximum } 10 /- \text { for any one patient. }\end{array}$ \\
\hline \multirow[t]{2}{*}{ Fillings } & Simple, from $1 /-$ to $5 /-$ \\
\hline & $\begin{array}{l}\text { Compound (including contour work } \\
\text { and root fillings) up to } 7 / 6\end{array}$ \\
\hline \multicolumn{2}{|l|}{ Mechanical } \\
\hline $\begin{array}{l}\text { Full (or nearly full) upper } \\
\text { or lower denture }\end{array}$ & $30 /-$ to $€ 2$ \\
\hline $\begin{array}{l}\text { Partial upper or lower } \\
\text { denture }\end{array}$ & $\begin{array}{l}5 /- \text { to } £ 2 \text { depending on the size } \\
\text { and difficulty of the case, including } \\
\text { necessary scaling }\end{array}$ \\
\hline $\begin{array}{l}\text { Remodelling old } \\
\text { dentures, upper or lower }\end{array}$ & $10 /-$ to $€ 1$ \\
\hline $\begin{array}{l}\text { Repairing broken } \\
\text { dentures }\end{array}$ & $5 /-$ \\
\hline
\end{tabular}

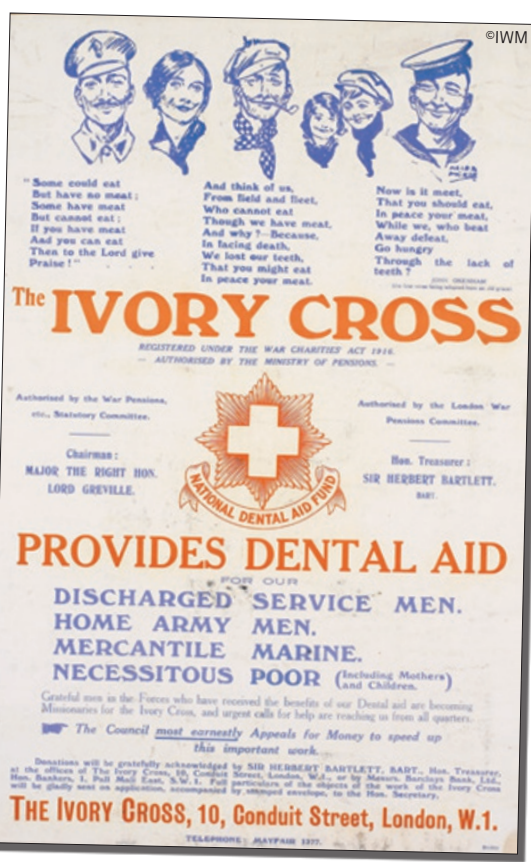

home army, mercantile marine and necessitous poor (including mothers and children). There was also a provision to educate the public in good oral hygiene. Ada Fletcher was proud that the office expenses of the fund were so low that of every $£ 1$ subscribed $18 \mathrm{~s}$ and $6 \mathrm{~d}$ was spent on dental treatment. The fund appointed a Dental Committee which consisted of leading dentists including the BDA President W. Dolomore and BDA Metropolitan Branch President W. Francis Mellersh.

The fund enjoyed generous support from well-respected members of the profession, society and royalty, and lavish dinners and entertainments were organised for such purposes. Dental manufacturing companies were keen to support the fund too.

The Ivory Cross on a rayed star was chosen to be the emblem and this badge was worn by dentists on the roll of honour on payment of half a crown. It was designed by John Seymour Lucas RA.

In January 1919 Ada Fletcher set up the Ivory Cross Journal to continue to spread the word about the fund. The fund continued to provide valuable treatment throughout the Second World War and finally wound up in 1948 at the start of the NHS having treated 77,000 patients.

With thanks to Rachel Bairsto, BDA Head of Museum Services.
HONOURS, AWARDS, APPOINTMENTS

Voluntary Service Award Two Longitudinal Dental Foundation Trainees (LDFTs) in Edinburgh have won the Voluntary Service Award at the NHS Lothian Celebrating Success Awards 2014. Niall Mc Goldrick and Orna Ni Choileain were nominated for being the driving force behind Let's Talk About Mouth Cancer, a campaign to raise awareness of mouth cancer in Edinburgh.

Chairman of the Board

Professor John Gibson has been appointed the new Chairman of the Board of Dental Protection Ltd. Professor Gibson is qualified in both dentistry and medicine and is Professor of Medicine in Relation to Dentistry and Honorary Consultant in Oral Medicine in Glasgow.

He is joined on the Board by Professor Callum Youngson who is Professor and Honorary Consultant in Restorative Dentistry at the University of Liverpool, and Dean of Liverpool Dental School.

\section{King's students awarded}

Five King’s College London Dental Institute students on three postgraduate MSc programmes have been selected to receive awards from Henry Schein to recognise students across the categories of leadership, academic excellence and hardship. Students Joshua Green and Takawira Mairosi are this year's Leadership awards winners and Mariacristina Ruberto is the recipient of this year's award for Excellence. Two additional awards were granted to students on the basis of financial need.

\section{SONNY AKPABIO}

We are sad to announce that Dr Sunday (Sonny) Prince Akpabio died peacefully after a long illness on 20 November, aged 90 . He is remembered with love by Thelma, Basi and Rachel.

A funeral for Dr Akpabio was scheduled for 8 December at the Church of St John the Baptist, Stone, Buckinghamshire.

An obituary will follow. 